\title{
Article/Artigo
}

\section{Long-term outcome of neuroparacoccidioidomycosis treatment}

\author{
Resultado de longo prazo no tratamento da neuroparacoccidioidomicose
}

\section{Fabio Francesconi ${ }^{1}$, Marcus Tulius Teixeira da Silva ${ }^{2}$, Regina Lana Braga Costa ${ }^{2}$, Valeska Albuquerque Francesconi ${ }^{1}$, Eleonora Carregal ${ }^{2}$, Sinésio Talhari ${ }^{3}$ and Antonio Carlos Francesconi do Valle ${ }^{2}$}

\begin{abstract}
Introduction: Neuroparacoccidioidomycosis (NPCM) is a term used to describe the invasion of the central nervous system by the pathogenic fungus Paracoccidioides brasiliensis. NPCM has been described sporadically in some case reports and small case series, with little or no focus on treatment outcome and long-term follow-up. Methods: All patients with NPCM from January 1991 to December 2006 were analyzed and were followed until December 2009. Results: Fourteen (3.8\%) cases of NPCM were identified out of 367 patients with paracoccidioidomycosis (PCM). A combination of oral fluconazole and sulfamethoxazole/ trimethoprim (SMZ/TMP) was the regimen of choice, with no documented death due to Paracoccidioides brasiliensis infection. Residual neurological deficits were observed in 8 patients. Residual calcification was a common finding in neuroimaging follow-up. Conclusions: All the patients in this study responded positively to the association of oral fluconazole and sulfamethoxazole/trimethoprim, a regimen that should be considered a treatment option in cases of NPCM. Neurological sequela was a relatively common finding. For proper management of these patients, anticonvulsant treatment and physical therapy support were also needed.
\end{abstract}

Keywords: Paracoccidioides brasiliensis. Neuroparacoccidioidomycosis.Treatment. Central nervous system infection.

\section{RESUMO}

Introdução: Neuroparacoccidioidomicose (NPCM) é um termo utilizado para descrever a invasão do sistema nervoso central pelo fungo patogênico Paracoccidioides brasiliensis. NPCM é descrita, esporadicamente, em relatos de casos ou pequenas séries de casos com pouco ou nenhum enfoque no tratamento ou acompanhamento de longo prazo. Métodos: Todos os pacientes com diagnóstico de NPCM entre janeiro de 1991 a dezembro de 2006 foram acompanhados até dezembro de 2009. Resultados: Foram identificados 14 (3,8\%) casos de NPCM de 367 pacientes com paracoccidioidomicose (PCM). Regime combinando fluconazol oral e sulfamethoxazol/trimetoprim (SMZ/TMP) foi o tratamento de escolha. Não houve nenhum caso de óbito causado pelo fungo Paracoccidioides brasiliensis.Sequela neurológica foi identificada em 8 pacientes. Durante o seguimento, calcificação residual foi um achado comum de neuroimagem. Conclusões: Todos os pacientes deste estudo responderam de forma favorável a associação do fluconazol com o sulfamethoxazol/trimetoprim, um esquema terapêutico que deve ser considerado nos casos de NPCM. Sequela neurológica foi um achado relativamente comum, desta forma, a utilização de anticonvulsivantes, assim como foi necessário suporte fisioterápico para um manejo adequado destes pacientes.

Palavras-chaves: Paracoccidioides brasiliensis. Neuroparacoccidioidomicose. Tratamento. Infecção do sistema nervoso central.

1. Dermatology Department, Manaus Oncology Control Foundation Center, Manaus, AM, Brazil. 2. Evandro Chagas Clinical and Research Institute, Oswaldo Cruz Foudation, Rio de Janeiro, RJ, Brazil. 3. Dermatology Department, Amazonas Tropical Medicine Foundation, Manaus, AM, Brazil.

Address to: Dr. Fabio Francesconi. Dept ${ }^{\circ}$ Dermatologia/FCECOM. Rua Francisco Orellana 215, Planalto, 69040-010 Manaus, AM, Brazil.

Phone: 5592 3655-4600

e-mail: fabiofrancesconi@globo.com

Received in 11/04/2010

Accepted in 06/10/2010

\section{INTRODUCTION}

Paracoccidioidomycosis (PCM) is a systemic fungal disease caused by the dimorphic fungus Paracoccidioides brasiliensis, with an annual incidence rate of 1 to 3 cases per 100.000 inhabitants in endemic areas ${ }^{1}$. It is endemic in several Latin American countries, especially in Brazil, which is responsible for at least $80 \%$ of all reported cases ${ }^{2}$. Non-autochthonous cases of PCM are considered to be imported disease from endemic countries.

Primary infection caused by P. brasiliensis is usually asymptomatic and normally occurs in the first two decades of life after inhaling the fungus conidia from the soil ${ }^{3}$. Some of these individuals develop PCM disease, but illness commonly occurs months or years after primary infection, the so-called chronic or adult-type $\mathrm{PCM}^{4}$. In $10 \%$ of cases or less, the disease develops acutely or sub-acutely soon after primary infection, namely acute or juvenile-type $\mathrm{PCM}^{5}$.

Following primary infection, the lungs are compromised in at least $90 \%$ of all chronic cases. After hematogenous and or lymphatic dissemination, any other organ or system may be affected, principally the mucous membranes of the aerodigestive system, lymph nodes, skin and adrenal glands. The juvenile-type PCM usually manifests with extra-pulmonary disease affecting the mononuclear phagocytic system ${ }^{5}$.

Central nervous system (CNS) disease caused by P. brasiliensis is mainly described as a manifestation of the chronic PCM. Its real prevalence is unknown, though case series report neurological disease in $4.1 \%$ to $13.9 \%$ of PCM patients $^{6-9}$. In this study, all NPCM cases that occurred over a 15-year period at a referral center for PCM in Rio de Janeiro, Brazil, were described. Treatment outcome and long-term followup were the scope of this study. Since none of the reported case series focused on treatment outcome or discussed long-term follow-up, the authors believe that this report can make an important contribution to current knowledge regarding NPCM. 


\section{METHODS}

All patients diagnosed with NPCM at FIOCRUZ, from January 1991 to December 2006, were included in this study and followed until December 2009. As a routine, all PCM patients are submitted to clinical, dermatological, neurological and otolaryngological examination. The routine laboratorial tests include HIV serology, ACTH stimulation test, sputum examination for mycological and bacterial analysis, stool examination and serum doubleimmunodiffusion serology for $P$. brasiliensis. Further investigation with neuroimaging was performed in all cases with neurological symptoms or complaints. Cerebrospinal fluid (CSF) analysis was performed in selected cases.

The criteria used to define NPCM were evidence of P. brasiliensis infection in the CNS (brain biopsy or positive double-immunodiffusion test in CSF) or unequivocal evidence of $P$. brasiliensis infection in other organs associated with one or more CNS lesions in neuroimaging and posterior involution with specific treatment.

The treatment protocol used was sulfamethoxazole $(2.400 \mathrm{mg})$ plus trimethoprim (480mg) for 2 months followed by sulfamethoxazole $(1.600 \mathrm{mg})$ plus trimethoprim $(320 \mathrm{mg})$ until the end of the treatment. The dose of fluconazole was $200 \mathrm{mg}$ a day from beginning to end of treatment.

\section{RESULTS}

Between January 1991 and December 2006, 367 consecutive PCM patients were admitted to the FIOCRUZ. Fourteen patients (3.8\%) (Table 1) were diagnosed with NPCM. One out of 14 was classified as juvenile-type PCM (patient 3$)^{10}$; the remaining 13 were classified as adult-type PCM.

All patients came from endemic areas and reported a prior history of soil related labor. The median age at diagnosis was 41.78 years-old, ranging from 21 to 57 years of age. Thirteen patients were addicted to tobacco cigars.
All patients presented clinical evidence of $P$. brasiliensis, with positive mycological culture in at least one other organ or tissue (multifocal disease) (Table 1). Evidence of pulmonary disease was detected in 13 (93\%) patients. Other organs/systems affected were mucous membranes of the aerodigestive system ( 11 patients), adrenal glands ( 7 patients), lymph nodes ( 5 patients), skin (3 patients) and bone, tongue and liver (1 patient each). Systemic symptoms (fever, weight loss, and anorexia) were present in 12 patients.

Considering symptom chronology, 11 patients presented systemic symptoms before neurological complaints, with a mean period of 24 months ( 7 to 43 ). In 5 of these cases, CNS disease occurred after relapse of the PCM during irregular treatment. CNS disease presented concomitantly with symptoms in other organ in one patient and was the index manifestation in two (Table 1).

The most common neurological manifestation was seizure (57\%) followed by hemiparesis (29\%), headache (21\%) and ataxia (21\%). One patient presented spinal cord compression due to an intramedullary, nodular-enhanced lesion at D12 (patient 14) ${ }^{11}$. Another patient presented a subacute meningoencephalitis with diffuse cortical contrast enhancement without focal brain lesions in brain computed tomography (CT) scan (patient 3$)^{10}$. In two patients, the neurological disease initially manifested with psychiatric symptoms.

CSF analysis was performed on 5 patients. It was only useful in case 3 (patient with subacute meningoencephalitis), where the liquor double-immunodiffusion test presented positive titers of 1:64 ${ }^{10}$.

Computed tomography scan diagnosed a total of 39 brain lesions in 12 patients. Granulomatous, pseudotumoral form was observed in 11 patients; in 3 meningeal enhancement was also observed. Brain lesions varied from 8.5 to $35 \mathrm{~mm}$ in size (median of $18.8 \mathrm{~mm}$ ) and $95 \%$ of these exhibited contrast enhancement (ring-enhancement in 32 and nodular enhancement in 7 lesions). Supratentorial lesions were seen in $64 \%$ of patients and in $21 \%$ of cases the lesions were located both supra and infratentorially.

A combination of oral fluconazole and sulfamethoxazole/ trimethoprim was the regimen of choice (Table 1). The treatment

TABLE 1 - Clinical and laboratorial data of the patients.

\begin{tabular}{|c|c|c|c|c|c|c|c|c|c|}
\hline \multirow[b]{2}{*}{ Case } & \multirow[b]{2}{*}{ Age } & \multirow{2}{*}{$\begin{array}{l}\text { Cerebral } \\
\text { symptom }^{\mathrm{a}}\end{array}$} & \multirow{2}{*}{$\begin{array}{c}\text { Mycological } \\
\text { study }^{b}\end{array}$} & \multirow{2}{*}{$\begin{array}{l}\text { Number } \\
\text { of lesions }\end{array}$} & \multirow{2}{*}{$\begin{array}{l}\text { Calcified } \\
\text { lesions }\end{array}$} & \multirow{2}{*}{$\begin{array}{c}\text { Neurological } \\
\text { deficits }^{\mathrm{e}}\end{array}$} & \multicolumn{2}{|c|}{ Treatment } & \multirow[b]{2}{*}{ Follow-up ${ }^{h}$} \\
\hline & & & & & & & Scheduled ${ }^{f}$ & Durationg & \\
\hline 1 & 43 & $\mathrm{~A} / \mathrm{R}$ & tongue & 7 & - & - & $\mathrm{SMZ} / \mathrm{TMP}+\mathrm{F}$ & 24 & - \\
\hline 2 & 34 & A & lymph node & 4 & $\mathrm{Y}$ & $\mathrm{N}$ & $\mathrm{SMZ} / \mathrm{TMP}+\mathrm{F}$ & 24 & 98 \\
\hline 3 & 21 & $\mathrm{~A} / \mathrm{R}$ & mouth & 0 & $\mathrm{~N}$ & $\mathrm{~N}$ & $\mathrm{SMZ} / \mathrm{TMP}+\mathrm{F}$ & 36 & 194 \\
\hline 4 & 47 & $\mathrm{~A} / \mathrm{R}$ & lymph node & 4 & $\mathrm{Y}$ & seizure & $\mathrm{SMZ} / \mathrm{TMP}+\mathrm{F}$ & 24 & 151 \\
\hline 5 & 41 & A & mouth & 7 & $\mathrm{Y}$ & hemiparesis & $\mathrm{SMZ} / \mathrm{TMP}+\mathrm{F}$ & 30 & 26 \\
\hline 6 & 50 & A & spumtum & 4 & $\mathrm{Y}$ & $\mathrm{N}$ & SMZ/TMP & 58 & 43 \\
\hline 7 & 40 & $\mathrm{~B}$ & brain & 1 & $\mathrm{~N}$ & seizure, hemiparesis & $\mathrm{SMZ} / \mathrm{TMP}+\mathrm{F}$ & 84 & 30 \\
\hline 8 & 39 & B & larynx & 2 & $\mathrm{~N}$ & cognitive deficit & $\mathrm{SMZ} / \mathrm{TMP}+\mathrm{F}$ & 37 & 64 \\
\hline 9 & 52 & A & larynx & 1 & $\mathrm{~N}$ & $\mathrm{~N}$ & SMZ/TMP & 33 & 12 \\
\hline 10 & 46 & A & brain & 8 & $\mathrm{Y}$ & ataxia & $\mathrm{SMZ} / \mathrm{TMP}+\mathrm{F}$ & 24 & 138 \\
\hline 11 & 45 & A & spumtum & 1 & $\mathrm{Y}$ & seizure & Itraconazole & 40 & 20 \\
\hline 12 & 39 & $\mathrm{~A} / \mathrm{R}$ & brain & 1 & $\mathrm{~N}$ & $\mathrm{~N}$ & $\mathrm{SMZ} / \mathrm{TMP}+\mathrm{F}$ & 52 & 49 \\
\hline 13 & 41 & $\mathrm{C}$ & mouth & 1 & $\mathrm{Y}$ & seizure & SMZ/TMP & 80 & 12 \\
\hline 14 & 32 & $\mathrm{~A} / \mathrm{R}$ & spumtum & 1 & - & paraparesis & $\mathrm{SMZ} / \mathrm{TMP}+\mathrm{F}$ & 36 & 196 \\
\hline
\end{tabular}

a: onset of neurological disease in relation with systemic PCM, b: place where samples were taken for PCM diagnosis, c: number of lesions observed at first brain computed tomography scan, $\mathrm{d}$ : calcified lesions present in computed tomography scan performed after treatment, e: Residual deficit at the last visit, $\mathrm{f}$ : treatment used, g: length of treatment in months, h: follow-up after withdrawal of treatment (in months). A: after, B: before, C: concomitantly, R: cerebral PCM during relapse, Y: yes, N: no, SMZ/TMP: sulfamethoxazole/trimethoprim, F: fluconazole. 
was maintained for a mean period of 41.57 months ( 24 to 84 months). The criteria for ceasing treatment were absence of disease activity based on systematic clinical examination of the patient, a reduction in serology titers and improvement in radiological studies. In addition to clinical treatment, surgery was indicated for the patient with spinal cord lesion.

One patient presented severe allergy to ketoconazole, amphotericin B, fluconazole and sulfamethoxazole/trimethoprim. He was treated with itraconazole, based on a publication written by Villa et $\mathrm{al}^{12}$.

Posttreatment follow-up was maintained for a mean period of 73.78 months (12 to 196 months). One patient died of a
non-PCM related cause during follow-up (patient 1; cardiac shock). Residual neurological deficits were observed in eight patients, with seizure and motor deficit the most common symptoms reported (Table 1). The use of anticonvulsants was necessary in six patients and this was maintained in four.

A control CT scan was performed in nine patients during the first year of follow-up ( 27 brain lesions) and in seven patients during the second year ( 22 brain lesions). The size and the intensity of edema were the first signs to show alteration under the treatment, followed by diminished lesions. Approximately one third of lesions calcified after 23 months. In seven patients, at least one normal brain CT scan was performed before the appearance of a calcified lesion (Figure 1).

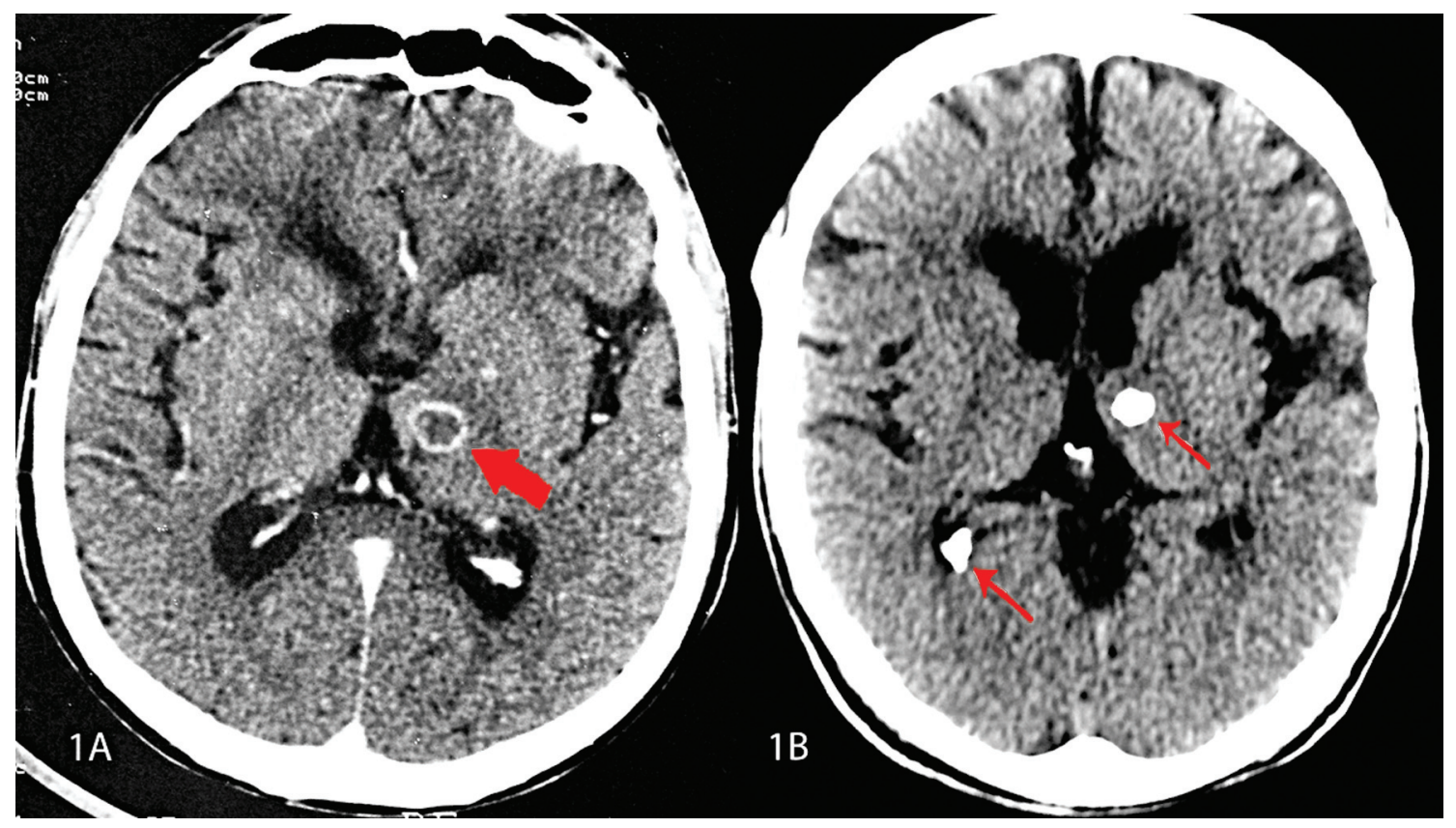

FIGURE 1 - Brain computed tomography scan of a patient with cerebral paracoccidioidomycosis showing a hypodense, ring-enhanced lesion in the left thalamus surrounded by mild edema ( $1 \mathrm{~A}$ - arrow). A dense calcification was observed several months after treatment (1B - thin arrow).

\section{DISCUSSION}

The real prevalence of cerebral PCM is unknown. In the present cohort, cerebral PCM was diagnosed in 14 out of 367 PCM patients, showing a prevalence of $3.8 \%$; in other clinical series the prevalence ranged from $4.1 \%$ to $13.9 \%$. On the other hand, imaging studies with computed tomography (CT) showed a prevalence of NPCM in $12.5 \%$ of cases ( 5 out of 40 asymptomatic patients) and magnetic resonance (MR) in $40 \%$ of cases ( 10 out of 25 patients, 8 of which were asymptomatic). Although these radiological studies involved few patients, they suggest that neurological disease may be more common than routinely thought $t^{6-9,13-15}$.

The cases in this work all presented multifocal disease and in all cases, it was possible to isolate $P$. brasiliensis from the affected organs (Table 1). The notion of multifocal disease in PCM and the rarity of unifocal neurological disease should prevent unnecessary brain biopsy in patients with suspicion of NPCM.

It is still unclear what the treatment of choice for NPCM should be. A systematic review of all published cases of NPCM up to 2007 showed that sulfonamide-based treatment, amphotericin B and surgery were the most common treatment approaches used, with an overall mortality rate of $44.1 \%^{16}$. Although amphotericin B is the drug of choice for severe cases, it is well known that this drug does not have good penetration into the blood-brain barrier and should ideally be used intrathecally for fungal infections of the CNS. Voriconazole is a good therapeutic option for NPCM, due to its action against $P$. brasiliensis and its good penetration into the CNS. Costs limit their routine use. Itraconazole also does not have adequate penetration into the $\mathrm{CNS}^{5}$.

Most of the patients described here were treated with an association of fluconazole and SMZ/TMP. With a median follow-up of 73.78 months ( 12 to 196 months) no case of relapse or mortality was observed. The first case in which the association was used was a patient with a history of irregular use of SMZ/TMP, who relapsed with neurological disease. Considering a theoretical possibility of resistance to SMZ/TMP alone, the good penetration of fluconazole in the CNS and the high mortality rate of NPCM, the authors decided to initiate this association. The good outcome of the case prompted the use of this association in other cases of NPCM. 
In five patients, the neurological disease appeared after a period of irregular treatment schedule. This fact suggests that the CNS may represent a sanctuary to the fungus and contribute to disease relapse in nonadherent patients.

This study is the first to highlight the importance of neurological sequelae in the management of NPCM, emphasizing the need to control seizures and physiotherapy support. After completing the specific antifungal therapy, anticonvulsive treatment was maintained in four patients. Three patients were unable to regain muscle strength, despite physiotherapy.

The evolution of neurological imaging is also noteworthy. This paper shows that calcification can appear after a period of apparently normal CT scans and NPCM should be considered in the differential diagnosis of cerebral calcification of unknown cause in endemic areas of PCM.

This study has certain weaknesses. First of all, the treatment schedule is based on first-hand experience of the professionals at our service and should be tested in a multicentric, prospective, doubleblind study. The association of fluconazole and SMZ/TMP should also be tested in well planned pharmacological studies. On the other hand, NPCM occurs in many poor areas with no access to certain drugs or neuroimaging exams, making the ideal study difficult to conduct. The period of treatment should be programmed individually, based on clinical, radiological, serological and laboratorial data. Neurological sequelae are also an important morbidity that should be considered by all professionals that deal with PCM.

Considering patients who live in rural endemic regions for PCM, NPCM should be included in the differential diagnosis regarding any neurological clinical picture. The association of fluconazole with SMZ/TMP appears to be a viable option in the treatment of patients with NPCM and should at least be considered in cases where other treatment schedules are not working as expected. Anticonvulsive therapy and physiotherapy are necessary to correctly manage the patients afflicted by neurological symptoms, at any stage of the disease, including active disease, symptomatic central nervous system calcification or neurological sequelae.

\section{ACKNOWLEDGMENTS}

The authors are grateful to Professor Joseph Zunt for kindly reviewing the manuscript.

\section{CONFLICT OF INTEREST}

The authors declare that there are no conflicts of interest.

\section{FINANCIAL SUPPORT}

This study was partially supported by the Ministério da Saúde and Fundação Oswaldo Cruz.

\section{REFERENCES}

1. Wanke B, Londero A. Epidemiology of paracoccidioidomycosis infection. In: Franco M, Lacaz C, Restrepo M, editors. Paracoccidioidomycosis. Boca Raton: CRC Press; 1994.p.109-117.

2. Restrepo A. The ecology of Paracoccidioides brasiliensis: a puzzle still unsolved. Sabouraudia 1985;23:323-334.
3. Albornoz MB, Albornoz R. Isolation of Paracoccidioides brasiliensis from rural soil in Venezuela. Sabouraudia 1971;9:248-253.

4. Montenegro MR, Franco M. Pathology. In: Franco M, Lacaz C, Restrepo-Moreno A, Del Negro G, editors. Paracoccidioidomycosis London: CRC Press; 1994; p.131-150.

5. Shikanai-Yasuda MA, Telles Filho F de Q, Mendes RP, Colombo AL, Moretti ML. Guidelines in paracoccidioidomycosis. Rev Soc Bras Med Trop2006; 39:297-310.

6. De Almeida SM, Queiroz-Telles F, Teive HA, Ribeiro CE, Werneck LC. Central nervous system paracoccidioidomycosis: clinical features and laboratorial findings. J Infect 2004;48:193-198.

7. Paniago AMM, Oliveira PA, Aguiar ESA, Aguiar JIA, Cunha RV, Leme LM, et al. Neuroparacoccidioidomycosis: analysis of 13 cases observed in an endemic area in Brazil. Trans R Soc Trop Med Hyg 2007;101:414-420.

8. Pla MP, Hartung C, Mendoza P, Stukanoff A, Moreno MJ Neuroparacoccidioidomycosis: case reports and review. Mycopathologia 1994;127:139-144.

9. Elias Jr J, dos Santos AC, Carlotti Jr CG, Colli BO, Canheu A, Matias C, et al. Central nervous system paracoccidioidomycosis: diagnosis and treatment. Surg Neurol2005;63(suppl 1):S13-21.

10. Francesconi F, do Valle ACF, Silva MTT, Costa RLB, Carregal E, Talhari S. Meningoencephalitis due to Paracoccidioides brasiliensis. Neurology 2008;71:e65-e67.

11. do Valle AC, Skacel M, Costa RL, Ribeiro CT, Montagna NA, da Cruz LC A case report of intraspinal paracoccidioidomycosis. Rev Inst Med Trop Sao Paulo 1998;40:203-207.

12. Villa LA, Tobón A, Restrepo A, Calle D, Rosero DS, Gómez BL. Central nervous system paracoccidioidomycosis. Report of a case successfully treated with itraconazol. Rev. Inst. Med. Trop. Sao Paulo 2000;42:231-234.

13. Hutzler RU, Brussi ML, Capitani Cde M, Lima SS. Neurological involvement of paracoccidioidomycosis, evaluated by computerized skull tomography. Rev Paul Med 1985;103:243-244.

14. Fagundes-Pereyra WJ, Carvalho GT, Miranda Goes A, Chagas Lima e Silva F Sousa AA. Central nervous system paracoccidioidomycosis: analysis of 13 cases. Arq Neuropsiquiatr 2006; 64:269-276.

15. de Castro CC, Benard G, Ygaki Y, Shikanai-Yasuda MA. MRI of head and neck paracoccidioidomycosis. Br J Radiol 1999; 72:717-722

16. Pedroso VS, Vilela Mde C, Pedroso ER, Teixeira AL. Paracoccidioidomycosis compromising the central nervous system: a systematic review of the literature. Rev Soc Bras ed Trop 2009; 42:691-697. 